\title{
Halogenated organic species over the tropical South American rainforest
}

\author{
S. Gebhardt ${ }^{1}$, A. Colomb ${ }^{2}$, R. Hofmann ${ }^{1}$, J. Williams ${ }^{1}$, and J. Lelieveld ${ }^{1}$ \\ ${ }^{1}$ Max Planck Institute for Chemistry, Mainz, Germany \\ ${ }^{2}$ Laboratoire Interuniversitaire des Systèmes Atmosphériques (LISA), Paris, France
}

Received: 13 November 2007 - Published in Atmos. Chem. Phys. Discuss.: 23 January 2008

Revised: 25 April 2008 - Accepted: 21 May 2008 - Published: 24 June 2008

\begin{abstract}
Airborne measurements of the halogenated trace gases methyl chloride, methyl bromide and chloroform were conducted over the Atlantic Ocean and about $1000 \mathrm{~km}$ of pristine tropical rainforest in Suriname and French Guyana $\left(3-6^{\circ} \mathrm{N}, 51-59^{\circ} \mathrm{W}\right)$ in October 2005 . In the boundary layer $(0-1.4 \mathrm{~km})$, maritime air masses, advected over the forest by southeasterly trade winds, were measured at various distances from the coast. Since the organohalogens presented here have relatively long atmospheric lifetimes (0.41.0 years) in comparison to the advection times from the coast (1-2 days), emissions will accumulate in air traversing the rainforest. The distributions of methyl chloride, methyl bromide and chloroform were analyzed as a function of time the air spent over land and the respective relationship used to determine net fluxes from the rainforest for one week within the long dry season.

Net fluxes from the rainforest ecosystem have been calculated for methyl chloride and chloroform as $9.5( \pm 3.82 \sigma)$ and $0.35( \pm 0.152 \sigma) \mu \mathrm{g} \mathrm{m}^{-2} \mathrm{~h}^{-1}$, respectively. No significant flux was observed for methyl bromide within the limits of these measurements.

The global budget of methyl chloride contains large uncertainties, in particular with regard to a possible source from tropical vegetation. Our measurements are used in a large-scale approach to determine the net flux from a tropical ecosystem to the planetary boundary layer. The obtained global net flux of $1.5( \pm 0.62 \sigma) \mathrm{Tg} \mathrm{yr}^{-1}$ for methyl chloride is at the lower end of current estimates for tropical vegetation sources, which helps to constrain the range of tropical sources and sinks ( 0.82 to $8.2 \mathrm{Tg} \mathrm{yr}^{-1}$ from tropical plants, 0.03 to $2.5 \mathrm{Tg} \mathrm{yr}^{-1}$ from senescent/dead leaves and a sink of 0.1 to $1.6 \mathrm{Tg} \mathrm{yr}^{-1}$ by soil uptake). Nevertheless, these results
\end{abstract}

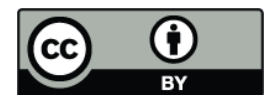

Correspondence to: J. Williams (williams@mpch-mainz.mpg.de) show that the contribution of the rainforest ecosystem is the major source in the global budget of methyl chloride.

For chloroform, the extrapolated global net flux from tropical ecosystems is $56( \pm 232 \sigma) \mathrm{Gg} \mathrm{yr}^{-1}$, which is of minor importance compared to the total global sources and might be already contained in the soil emission term.

\section{Introduction}

Halogenated organic compounds have been shown to be important to the chemistry of both the troposphere and the stratosphere (WMO, 2007a). Since these compounds have relatively long atmospheric lifetimes (methyl chloride $1.0 \mathrm{yr}$, methyl bromide $0.7 \mathrm{yr}$, chloroform $0.41 \mathrm{yr}$; WMO, 2007b), they can effectively transport halogen atoms from surface sources to the stratosphere, and thereby significantly contribute to stratospheric ozone loss (Stolarski and Cicerone, 1974; Wofsy et al., 1975; Levine et al., 2007). Because the anthropogenic contribution to the organohalogen budget is now regulated by the Montreal Protocol, the ambient concentrations of many such halogenated compounds are stabilizing or declining (WMO, 2003). Therefore the relative influence of naturally produced halocarbons is becoming more important for the budgets of ozone depleting substances. Methyl chloride $\left(\mathrm{CH}_{3} \mathrm{Cl}\right)$ and methyl bromide $\left(\mathrm{CH}_{3} \mathrm{Br}\right)$ are both in part naturally emitted and are the most abundant chlorine and bromine containing gases in the troposphere, respectively. Currently $\mathrm{CH}_{3} \mathrm{Cl}$ contributes up to $16 \%$ to the tropospheric organic chlorine and $\mathrm{CH}_{3} \mathrm{Br}$ up to about $50 \%$ to the organic bromine (WMO, 2003). It is estimated that the contribution of natural $\mathrm{CH}_{3} \mathrm{Cl}$ and $\mathrm{CH}_{3} \mathrm{Br}$ to the equivalent effective stratospheric chlorine will rise to more than $50 \%$ (currently $23 \%$ ) by 2050 (WMO, 2007a). Despite its small total contribution to stratospheric ozone loss, chloroform $\left(\mathrm{CHCl}_{3}\right)$ is

Published by Copernicus Publications on behalf of the European Geosciences Union. 
an important natural source of tropospheric chlorine. Therefore it is important to determine the global budgets of these compounds.

The global average concentration of $\mathrm{CH}_{3} \mathrm{Cl}$ is approximately $550 \pm 30 \mathrm{pmol} \mathrm{mol}^{-1}$ with higher mixing ratios observed at low latitudes (Thompson et al., 2004). Small downward trends have been reported recently from the AGAGE measuring sites (Simmonds et al., 2004). Following the emission data provided by WMO (2007b) and references therein, the sources and sinks of $\mathrm{CH}_{3} \mathrm{Cl}$ are shown in Table 1. This list compiled from the latest available summary papers (Lobert et al., 1999; McCulloch, 2003; WMO, 2003 and WMO, 2007b) presents the global budget of the investigated compounds. It includes all established sources and sink terms. The range of these numbers is an indication of how well these terms are currently determined. The net effect on the atmosphere is given by the sum of all these sources and sinks. Earlier global budget estimates indicated that biomass burning was the main $\mathrm{CH}_{3} \mathrm{Cl}$ source (WMO, 1999). However, after Keene et al. (1999) and Butler (2000) highlighted an imbalance in the budget of this species, a new dominant source of $\mathrm{CH}_{3} \mathrm{Cl}$ from tropical vegetation was discovered by Yokouchi et al. (2002) and subsequently verified by airborne field measurements of Scheeren et al. (2003). Although the sources of $\mathrm{CH}_{3} \mathrm{Cl}$ appear to balance the sinks, large uncertainties remain regarding the nature of the tropical source since few measurements are available from this region.

Although 50-60 times less abundant than $\mathrm{CH}_{3} \mathrm{Cl}, \mathrm{CH}_{3} \mathrm{Br}$ concentrations are of great interest. It has a 25 times higher ozone depletion potential than $\mathrm{CH}_{3} \mathrm{Cl}$, caused by the fact that on per atom basis bromine is 60 times more effective in destroying ozone than chlorine (WMO, 2007a). Due to emission restrictions related to the Montreal Protocol the global average concentration is decreasing from peak values of $9.2 \mathrm{pmol} \mathrm{mol}^{-1}$ in 1999 to currently about $7.9 \mathrm{pmol} \mathrm{mol}^{-1}$ ( WMO, 2007b). A summary of the present understanding of sources and sinks of $\mathrm{CH}_{3} \mathrm{Br}$ is given in Table 1. Although balanced within the uncertainties, sinks seem to outweigh the sources, pointing on an underestimated or yet unknown source term. Conversely, it is also conceivable that the atmospheric lifetime of $\mathrm{CH}_{3} \mathrm{Br}$ has been underestimated, which would help to explain the imbalance between sources and sinks (Reeves, 2003).

The budget of $\mathrm{CHCl}_{3}$ is reasonably balanced within the uncertainties and was summarized by McCulloch (2003) (see Table 1 for summary). The global distribution of $\mathrm{CHCl}_{3}$ is strongly biased between the two hemispheres with 1.7 times higher mixing ratios found in the northern hemisphere (Khalil and Rasmussen, 1999). Antarctic firn air measurements (Trudinger et al., 2004) show a steady increase from $4 \mathrm{pmol} \mathrm{mol}^{-1}$ around 1940 to peak values of $6.5 \mathrm{pmol} \mathrm{mol}^{-1}$ in 1990. After 1990 global observations show a downward trend. Global average mixing ratios of $18.5 \mathrm{pmol} \mathrm{mol}^{-1}$ between 1985 and 1995 (Khalil and Rasmussen, 1999) decreased to average background levels of
$8.9( \pm 0.1) \mathrm{pmol} \mathrm{mol}^{-1}$ in the years 1994-1998 (O’Doherty et al., 2001). However, a recent model study suggests that a higher anthropogenic contribution (41-50\% of the global sources) before 1990, versus 25-29\% in 2001, would explain the global observations better (Worton et al., 2006).

To gain an improved understanding of the global distribution of the sources of $\mathrm{CH}_{3} \mathrm{Cl}$ and $\mathrm{CH}_{3} \mathrm{Br}$ several model studies have been conducted in the past. Lee-Taylor et al. (2001) found that the observed mixing ratios of $\mathrm{CH}_{3} \mathrm{Cl}$ can be reproduced by the addition of a tropical terrestrial source of 2.33$2.43 \mathrm{Tg} \mathrm{yr}^{-1}$ and a reduction of Southeast Asian biomass burning emissions. The inverse model study of Yoshida et al. (2006) suggests a seasonally invariant additional source of $2.90 \mathrm{Tg} \mathrm{yr}^{-1}$ located in the tropics $\left(30^{\circ} \mathrm{N}-30^{\circ} \mathrm{S}\right)$ to explain the observed distribution.

Furthermore Lee-Taylor et al. (1998) find that the annual observations of $\mathrm{CH}_{3} \mathrm{Br}$ are best represented if an additional terrestrial net source of $89-104 \mathrm{Gg} \mathrm{yr}^{-1}$ is assumed, which is located for 50 to $71 \%$ in the southern hemisphere. A later 3-D global chemical transport model run performed by Warwick et al. (2006) used increased biomass burning emissions $\left(+20 \mathrm{Gg} \mathrm{yr}^{-1}\right)$ and an additional source of $45.6 \mathrm{Gg} \mathrm{yr}^{-1}$ $\mathrm{CH}_{3} \mathrm{Br}$ from tropical $\left(40^{\circ} \mathrm{N}-40^{\circ} \mathrm{S}\right)$ vegetation to reproduce the annual observations.

From model studies it appears that $\mathrm{CH}_{3} \mathrm{Cl}$ as well as $\mathrm{CH}_{3} \mathrm{Br}$ have tropical sources. Regarding $\mathrm{CH}_{3} \mathrm{Cl}$ there are some field studies, which support this thesis and the derived numbers are already incorporated in the global budget (see Table 1). However, due to the sparseness of these measurements the uncertainty of the sources is still very large.

Here we present large-scale airborne measurements of the organohalogen species $\mathrm{CH}_{3} \mathrm{Cl}, \mathrm{CH}_{3} \mathrm{Br}$ and $\mathrm{CHCl}_{3}$ over the rainforest of Suriname and French Guyana performed during one week within the long dry season (October) 2005, conducted within the Guyanas Atmosphere-Biosphere exchange and Radicals Intensive Experiment with the Learjet (GABRIEL) project. Additional information on the projects background and objective and additionally measured parameters can be found at http://www.mpch-mainz.mpg. $\mathrm{de} / \sim$ scheeren/gabriel/ and in the supplementary material of Lelieveld et al. (2008). The vertical and horizontal distributions of these species are analyzed and fluxes from the rainforest ecosystem are determined. The influence of biomass burning and entrained air on the derived fluxes is discussed and an extrapolation to the global scale made based on the new data. Tropical rainforest regions are important to investigate for organohalogens, not only because few measurements have been made so far but also their proximity to the Intertropical Convergence Zone (ITCZ) means that any emission there will have a strong chance of being transported into the stratosphere by the regionally prevalent deep convection (Holton, 1992). 
S. Gebhardt et al.: Halocarbons over the rainforest

Table 1. Current best estimate of the sources and sinks of $\mathrm{CH}_{3} \mathrm{Cl}, \mathrm{CH}_{3} \mathrm{Br}$ and $\mathrm{CHCl}_{3}$.

\begin{tabular}{|c|c|c|c|c|c|c|c|}
\hline & & \multirow[t]{2}{*}{ Source type } & \multicolumn{2}{|c|}{$\begin{array}{l}\text { Source range } \\
\text { /Gg yr-1 }\end{array}$} & \multirow[t]{2}{*}{ Sink type } & \multicolumn{2}{|c|}{$\begin{array}{c}\text { Sink range } \\
\text { /Gg yr-1 }\end{array}$} \\
\hline & & & $\min$ & $\max$ & & $\min$ & $\max$ \\
\hline \multirow[t]{12}{*}{$\mathrm{CH}_{3} \mathrm{Cl}$} & \multirow[t]{12}{*}{$\mathrm{a}$} & Tropical and subtropical plants & 820 & 8200 & $\mathrm{OH}$ reaction & 3800 & 4100 \\
\hline & & Tropical senescent or dead leaves & 30 & 2500 & Loss to stratosphere & 100 & 300 \\
\hline & & Biomass burning & 325 & 1125 & $\mathrm{Cl}$ reaction & 180 & 550 \\
\hline & & Oceans & 380 & 500 & Soils & 100 & 1600 \\
\hline & & Salt marshes & 65 & 440 & Loss to polar oceans & 93 & 145 \\
\hline & & Fungi & 43 & 470 & & & \\
\hline & & Wetlands & 48 & 48 & & & \\
\hline & & Rice Paddies & 2.4 & 4.9 & & & \\
\hline & & Fossil fuel burning & 5 & 205 & & & \\
\hline & & Waste incineration & 15 & 75 & & & \\
\hline & & Industrial processes & 10 & 10 & & & \\
\hline & & Total & 1743 & 13578 & Total & 4273 & 6695 \\
\hline \multirow[t]{12}{*}{$\mathrm{CH}_{3} \mathrm{Br}$} & \multirow[t]{12}{*}{$\mathrm{b}$} & Oceans & 23 & 119 & $\mathrm{OH}$ reaction and photolysis & 60 & 100 \\
\hline & & Fumigation & 28.2 & 64.4 & Oceans & 37 & 133 \\
\hline & & Gasoline & 0 & 10 & Soils & 32 & 154 \\
\hline & & Biomass burning & 10 & 40 & & & \\
\hline & & Wetlands & 2.3 & 9.2 & & & \\
\hline & & Salt marshes & 7 & 29 & & & \\
\hline & & Shrublands & 0.5 & 2 & & & \\
\hline & & Rapeseed & 4.8 & 8.4 & & & \\
\hline & & Rice paddies & 0.5 & 2.5 & & & \\
\hline & & Fungi & 0.5 & 5.2 & & & \\
\hline & & Peatlands & 0.1 & 3.3 & & & \\
\hline & & Total & 77 & 293 & Total & 129 & 387 \\
\hline \multirow[t]{9}{*}{$\mathrm{CHCl}_{3}$} & \multirow[t]{9}{*}{$\mathrm{c}$} & Open Oceans & 270 & 450 & $\mathrm{OH}$ reaction & 370 & 830 \\
\hline & & Soil processes & 120 & 320 & Soils & \multirow{7}{*}{\multicolumn{2}{|c|}{ not quantified }} \\
\hline & & Volcanic and geological sources & 9 & 15 & & & \\
\hline & & Anaerobic fermentation & 2 & 4 & & & \\
\hline & & Pulp and paper manufacture & 26 & 42 & & & \\
\hline & & Water treatment & 8 & 34 & & & \\
\hline & & Other industrial sources & 9 & 13 & & & \\
\hline & & Biomass burning ${ }^{d}$ & 2 & 2 & & & \\
\hline & & Total & 446 & 880 & Total & 370 & 830 \\
\hline
\end{tabular}

a after WMO (2007b) and references therein

$\mathrm{b}$ after WMO (2003) and references therein

c after McCulloch (2003)

d (Lobert et al., 1999)

This study enables us to determine the net flux from a large area well suited to extrapolate to global scale, because it inherently accounts for all possible interfering sources and sinks.

\section{Sampling and analysis}

\subsection{Sample collection}

In total 99 pressurised air samples were collected during 10 flights between $0-11 \mathrm{~km}$ over the tropical rainforest (see Fig. 1) using a custom-built automated air sampling system (Williams et al., 2007). The system consisted of a module containing $180.8 \mathrm{~L}$ electropolished stainless steel canisters and was installed within an adapted wingpod on a Learjet 


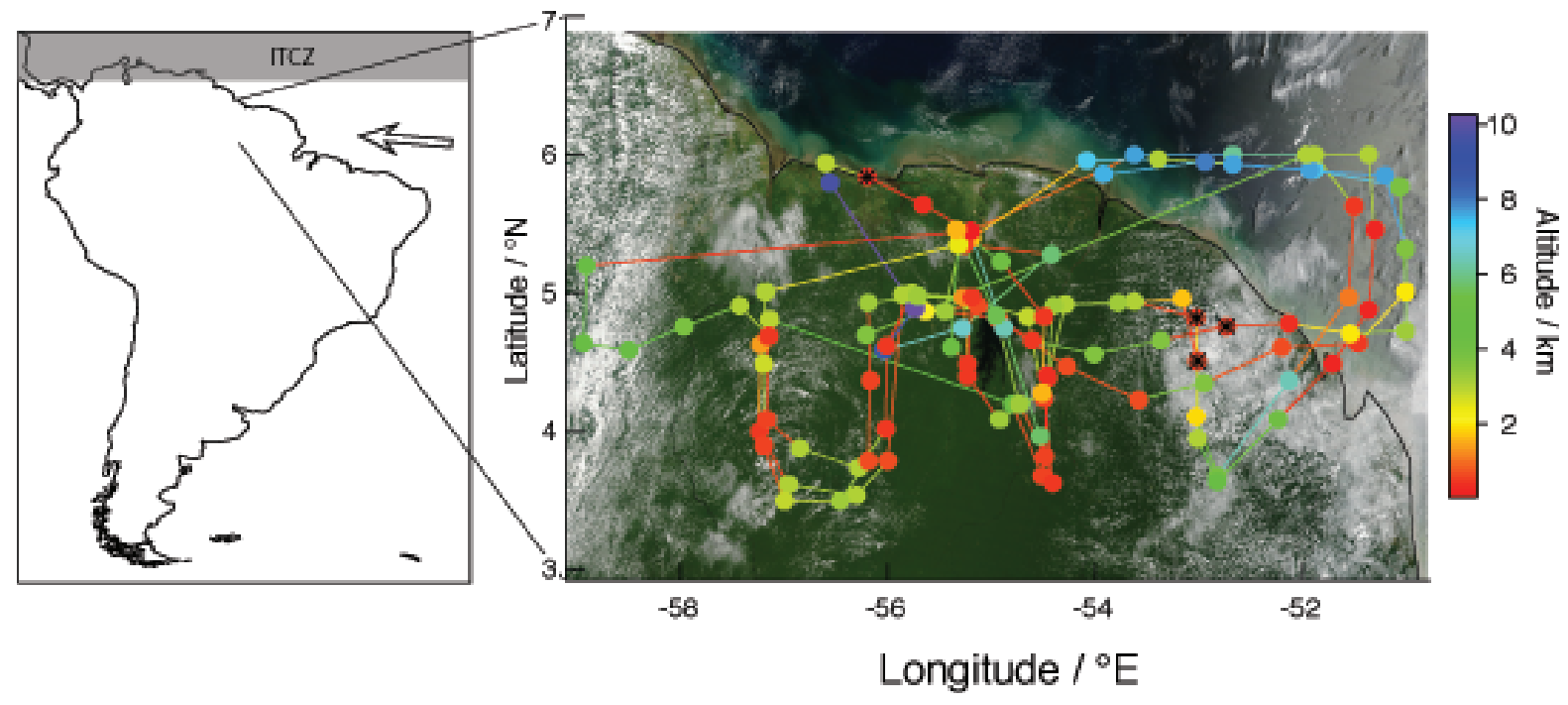

Fig. 1. Sampling area and flight tracks: ITCZ and prevailing wind direction (arrow) are shown on the left. On the right side dots mark the position of the samples, while the color-coding gives the height information. Black asterisks mark samples excluded from the calculation (source of satellite picture: Jacques Descloitres, MODIS Rapid Response Team, NASA/GSFC; downloaded September 2007 from: http: //visibleearth.nasa.gov/).

aircraft (Learjet 35A D-CGFD operated by GFD, Hohn, Germany and Enviscope GmbH, Frankfurt, Germany). The entire sampling system was constructed from $1 / 4(=0.635 \mathrm{~cm})$ o.d. stainless steel tubing and connectors (Swagelok, Solon $\mathrm{OH}$, USA). The inlet and outlet valves of the canisters were actuated by electric valves (Clippard-24V, Fluitronics, Düsseldorf, Germany). Thorough leak testing was carried out prior to the flights by pressurizing the sampling system with helium and looking for leaks with a helium leak detector. An aircraft metal bellows pump (Senior Aerospace, Herfordshire, UK) was used to draw ambient air through the inlet, flush all tubing throughout the flight and, when the fill valve was activated, to pressurise the canister to at least 3 bar $(3000 \mathrm{hPa})$. Canisters were filled sequentially at $10-\mathrm{min}$ intervals without any in line drying agent. Depending on the ambient atmospheric pressure, filling took from less than $25 \mathrm{~s}$ at $500 \mathrm{~m}$ to around $60 \mathrm{~s}$ at $8.5 \mathrm{~km}$. Prior to flight, the canister module was evacuated to $10^{-4} \mathrm{hPa}$ and directly after landing the filled module was transferred to the laboratory for immediate $(<48 \mathrm{~h})$ analysis. Storage tests on similar canisters (Colomb et al., 2006) have indicated that the investigated halocarbons are stable over 60 days under dry and humid conditions.

Three identical modules were built, allowing flights to be performed in quick succession. Pressure, temperature and valve status were controlled and logged by a computer within the wingpod.

\subsection{Instrumental set up}

The instrumentation used for the canister analysis consisted of a gas chromatograph - mass spectrometer system (GC/MS 6890/5973, Agilent Technologies, Palo Alto CA, USA), modified from the commercial version for analysis of lowlevel ambient air samples (Gros et al., 2003).

Approximately $450 \mathrm{~mL}$ of the compressed air sample were introduced into the sampling inlet, dried by flushing through a magnesium perchlorate filled tube heated to $100^{\circ} \mathrm{C}$ and prefocussed by a cryo-concentrator unit (1/16 ss line filled with glass beads, cooled to $-70^{\circ} \mathrm{C}$ ). After the cryofocussing the line was rapidly heated to $200^{\circ} \mathrm{C}$ and the target compounds were flushed into the GC. The separating column was a $60 \mathrm{~m} \times 0.248 \mathrm{~mm} \times 1 \mu \mathrm{m}$ DB- 5 capillary column $(\mathrm{J} \& \mathrm{~W}$ Scientific, Agilent Technologies, Palo Alto CA, USA). The temperature profile of the $\mathrm{GC}$ was ramped $\left(35^{\circ} \mathrm{C}\right.$ for $1 \mathrm{~min}$, heating at $8^{\circ} \mathrm{C} \mathrm{m^{-1 }}$ to $120^{\circ} \mathrm{C}$, hold $1 \mathrm{~min}$, further heating at $70^{\circ} \mathrm{C} \mathrm{min}^{-1}$ to $230^{\circ} \mathrm{C}$, hold $2 \mathrm{~min}$, hold $1 \mathrm{~min}$ at $200^{\circ} \mathrm{C}$ ). The chromatography parameters were optimised to enable good separation of circa 35 identified compounds; a complete run took about 18 minutes. The mass spectrometer was operated in Single Ion Mode (SIM) to achieve maximum sensitivity. Post flight, the filled canister module was attached to the GCMS system and the analysis proceeded semi automatically within $48 \mathrm{~h}$.

The detection limit was defined as three times the standard deviation of the noise (for the specific ion at its specific retention time). It was found to be $0.14 \mathrm{pmol} \mathrm{mol}^{-1}$ for $\mathrm{CHCl}_{3}, 0.51 \mathrm{pmol} \mathrm{mol}^{-1}$ for $\mathrm{CH}_{3} \mathrm{Br}$ and $1.9 \mathrm{pmol} \mathrm{mol}^{-1}$ for 
$\mathrm{CH}_{3} \mathrm{Cl}$. The overall uncertainty was calculated based on the accuracy of the calibration standard (5\%) and its precision $\left(\mathrm{CH}_{3} \mathrm{Cl} 3.2 \%, \mathrm{CHCl}_{3} 6.3 \%, \mathrm{CH}_{3} \mathrm{Br} 6.0 \%\right)$ and resulted in $5.9 \%$ for $\mathrm{CH}_{3} \mathrm{Cl}, 8 \%$ for $\mathrm{CHCl}_{3}$ and $7.8 \%$ for $\mathrm{CH}_{3} \mathrm{Br}$.

\subsection{Calibration}

Calibrations were performed against a whole air working standard, prepared by filling an aluminium cylinder with ambient suburban air using a three-stage oil-free piston compressor (RIX Industries, Benicia CA, USA) modified after Mak and Brenninkmeijer (1994). This cylinder was calibrated relative to a NIST primary standard at the National Centre for Atmospheric Research (NCAR, Boulder CO, USA). The working standard was analysed every five measurements. The average response factor of these analyses was used to calibrate the samples measured in between. At least one blank (using the same analytical procedure but without collecting an air sample) was performed at the start of each measurement sequence, and showed a generally clean baseline. Linearity of the system was confirmed in the range of measured concentrations $\left(\mathrm{CH}_{3} \mathrm{Cl}\right.$ 1.9-1900 pmol mol${ }^{-1}, \mathrm{CHCl}_{3}$ 0.14-470 $\mathrm{pmol} \mathrm{mol}^{-1}, \mathrm{CH}_{3} \mathrm{Br}$ $0.5-25 \mathrm{pmol} \mathrm{mol}^{-1}$ ). It should be noted that the $\mathrm{CHCl}_{3}$ mixing ratio in the calibration gas was significantly higher than in the ambient air samples.

\section{Results and discussion}

\subsection{Meteorological conditions in Suriname}

The northeast coast of South America is an excellent location to study the effects of the tropical rainforest on atmospheric trace gas composition. Meteorological conditions in this region are controlled by the steady trade winds and the annual migration of the ITCZ. The data presented here were collected from the 6 to the 13 of October 2005 within the GABRIEL project. During this time of the year - the long dry season - the ITCZ was located a few degrees north of the Guyanas at approximately $10-15^{\circ} \mathrm{N}$ (see Fig. 1). Thus, although geographically in the northern hemisphere, Suriname $\left(3-6^{\circ} \mathrm{N}, 51-59^{\circ} \mathrm{W}\right)$ was atmospherically located in the southern hemisphere. The location and height of all measurements is shown in Fig. 1.

During the campaign the meteorological conditions were generally constant with only occasional short thunderstorms. The cloud conditions observed were typical of tropical regions. This includes the development of shallow cumulus clouds in the morning, occasionally transforming into cumulonimbus clouds and hence thunderstorm activity in the late afternoon, before proceeding to clear sky in the evening. The prevailing wind direction in the boundary layer was easterly $\left(95^{\circ}\right)$, with average wind speeds of $5.8 \mathrm{~m} \mathrm{~s}^{-1}$, which is typical of the trade winds. Closer to the surface the wind weakened and turned to a more northeasterly direction as a result
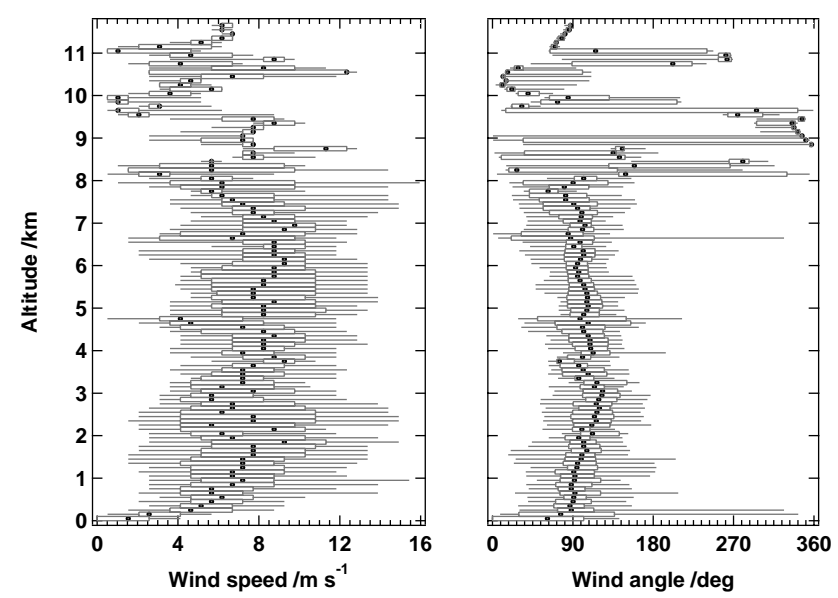

Fig. 2. Altitude distribution of wind speed and direction (angle) binned in $100 \mathrm{~m}$ intervals (dots: median, boxes: $25 / 75$ percentile, whiskers: $5 / 95$ percentile). A wind angle of $0^{\circ}$ is equivalent to northern direction. The data are $100 \mathrm{~m}$ binned average values of the $1 \mathrm{~Hz}$ data obtained by the aircraft flight management system via ARINC429.

of the increased friction with the surface. Wind speed and direction as a function of altitude are shown in Fig. 2.

Maritime air masses were advected from the Atlantic Ocean and then over approximately $1000 \mathrm{~km}$ of pristine rainforest. The 10-day back trajectories of the boundary layer samples are shown in Fig. 3. These indicate that air arriving at the coast of French Guyana and Suriname was transported for the most part within the southern hemisphere over the Atlantic Ocean.

The boundary layer height during the day, which is important in calculating the net flux, was determined using fluctuations in the static air temperature (corresponding to temperature inversions) measured from the aircraft when ascending (G. Eerdekens, personal communication). The temperature was recorded by the Enviscope analogue data acquisition system. Often there are a number of inversions present in the vertical profiles, and for this study we assumed that the lowest identifiable inversion delineates the top of the boundary layer. The derived boundary layer grew from about $600 \mathrm{~m}$ around 09:30 local time (UTC-3 h) to $1200 \mathrm{~m}$ at $12: 30$ up to about $1400 \mathrm{~m}$ in the afternoon. The empirically determined mixed layer height seems to be in agreement with the investigations by Krejci et al. (2005), who reported mixing layer heights from the same area in 1998. Because most of our measurements took place during midday or early afternoon, we considered an average boundary layer height of $1400 \mathrm{~m}$. The variability in the boundary layer height determinations between 12:00 and 16:00 was used to derive an uncertainty in the boundary layer height, which was determined to be $\pm 260 \mathrm{~m}(2 \sigma)$. 


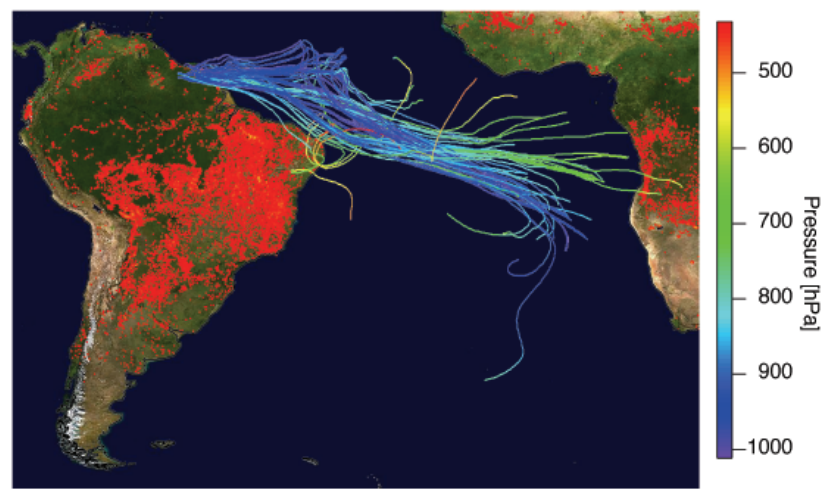

Fig. 3. 10-day back trajectories (provided by KNMI) of the canister samples taken within the boundary layer $(<1400 \mathrm{~m})$ overlaying a MODIS fire map showing all fires detected in the period from the 8 October 2005-18 October 2005 (Source: Fire maps created by Jacques Descloitres, MODIS Rapid Response System at NASA/GSFC; downloaded September 2007 from http://rapidfire. sci.gsfc.nasa.gov/firemaps/).

\subsection{Vertical distribution}

The vertical profiles of $\mathrm{CH}_{3} \mathrm{Cl}, \mathrm{CH}_{3} \mathrm{Br}$ and $\mathrm{CHCl}_{3}$ are presented in Fig. 4. The measurements span a range from the surface up to $11 \mathrm{~km}$ height, although air was predominantly sampled in the boundary layer. Generally the profiles could be divided into three different parts: The mixed boundary layer (ML) up to $1400 \mathrm{~m}$, the lower free troposphere below the trade wind inversion (LFT) from 1400 to $3500 \mathrm{~m}$ and the free troposphere (FT) above $3500 \mathrm{~m}$.

The $\mathrm{CH}_{3} \mathrm{Cl}$ profile showed higher mixing ratios near the ground decreasing with altitude. The average within the mixed layer was $643 \mathrm{pmol} \mathrm{mol}^{-1}$, decreasing to $600 \mathrm{pmol} \mathrm{mol}^{-1}$ within the LFT and further to $575 \mathrm{pmol} \mathrm{mol}^{-1}$ on average in the $\mathrm{FT}$; the one outlier (marked with BB in Fig. 4) is discussed further below.

The vertical distribution of $\mathrm{CH}_{3} \mathrm{Br}$ was quite scattered, which is in part due to the $7.8 \%$ precision error. The mixing ratios varied between 7.7 and $10.9 \mathrm{pmol} \mathrm{mol}^{-1}$ showing no significant trend with height.

The $\mathrm{CHCl}_{3}$ profile showed a decrease in mixing ratio from ML $\left(8.2 \mathrm{pmol} \mathrm{mol}^{-1}\right)$ to LFT $\left(7.0 \mathrm{pmol} \mathrm{mol}^{-1}\right)$. The average FT values were again slightly elevated $\left(7.5 \mathrm{pmol} \mathrm{mol}^{-1}\right)$. Taking into account the uncertainty of the data points no statistically significant information on the source distribution could be obtained from the vertical profiles. Nevertheless, on average higher mixed layer mixing ratios of $\mathrm{CH}_{3} \mathrm{Cl}$ and $\mathrm{CHCl}_{3}$ pointed to a ground based source of these compounds. This surface source is further investigated in Sect. 3.4.

The elevated value at $7.9 \mathrm{~km}$ visible in all three components corresponded to a sample taken within air strongly influenced by biomass burning, most probably originating from a distant biomass burning event in Africa. It coincided with elevated values in the biomass burning tracers carbon monoxide $(\mathrm{CO})$ and acetonitrile $\left(\mathrm{CH}_{3} \mathrm{CN}\right)(\mathrm{H}$. Bozem, personal communication).

\subsection{Influence of biomass burning}

As can be seen from the example above, the possible influence of biomass burning has to be considered when interpreting the mixing ratios of the investigated compounds. When considering natural fluxes, care must be taken to exclude burning effects from calculated gradients. Burning is known to be a strong source of $\mathrm{CH}_{3} \mathrm{Cl}$ and also a source of $\mathrm{CH}_{3} \mathrm{Br}$ and $\mathrm{CHCl}_{3}$ (Lobert et al., 1999; Andreae and Merlet, 2001). Since during the period September to November there is widespread burning in the southern hemisphere it would not be surprising if some influence of this was detected during this campaign, particularly in $\mathrm{CO}, \mathrm{CH}_{3} \mathrm{CN}$ and $\mathrm{CH}_{3} \mathrm{Cl}$. However, fire maps prepared from GOES-12 satellite images (http://cimss.ssec.wisc.edu/goes/ burn/wfabba.html) showed no significant burning activity in the direct vicinity of the investigated area. Furthermore, back trajectories from the measurement locations showed that the fires occurring south or west of the Guyanas had almost no impact on the investigated air masses in the boundary layer (see Fig. 3). Generally low levels of $\mathrm{CO}$ and $\mathrm{CH}_{3} \mathrm{CN}$ in the boundary layer (Stickler et al., 2007; G. Eerdekens, personal communication) also supported the view that the measurements were not significantly influenced by local burning sources. The ratio $\mathrm{CH}_{3} \mathrm{Cl} / \mathrm{CO}$ is one more parameter giving information on the sources of both gases. Other studies have reported $\mathrm{CH}_{3} \mathrm{Cl} / \mathrm{CO}$ ratios of $0.85( \pm 0.06) \times 10^{-3}$ for South American smouldering fires and $0.57( \pm 0.03) \times 10^{-3}$ for African flaming fires (Blake et al., 1996). During this study a $\mathrm{CH}_{3} \mathrm{Cl} / \mathrm{CO}$ ratio of $2.77( \pm 0.642 \sigma) \times 10^{-3}$ was obtained. The ratio measured here, lies clearly outside the reported range for biomass burning. Therefore we conclude that the predominant source of the observed $\mathrm{CH}_{3} \mathrm{Cl}$ in the boundary layer is most likely not biomass burning.

Since the vertical profile showed no statistically significant mixing ratio changes in the transition zone between ML and LFT, the influence of entrainment from upper layers of air is not taken into account in the following calculations.

\subsection{Net fluxes from the tropical forest}

As clean marine boundary layer air was advected westwards over the pristine tropical rainforest of French Guyana and Suriname during GABRIEL, mixing occurred between the marine boundary layer air and the forest emissions. Longlived trace gases emitted by the forest can accumulate in the mixed boundary layer so that mixing ratios of such species will increase westwards and hence be positively correlated with the time the air spent over land. Conversely uptake of gases by the forest will result in a negative correlation. The volume mixing ratios of $\mathrm{CH}_{3} \mathrm{Cl}, \mathrm{CH}_{3} \mathrm{Br}$ and $\mathrm{CHCl}_{3}$ samples 


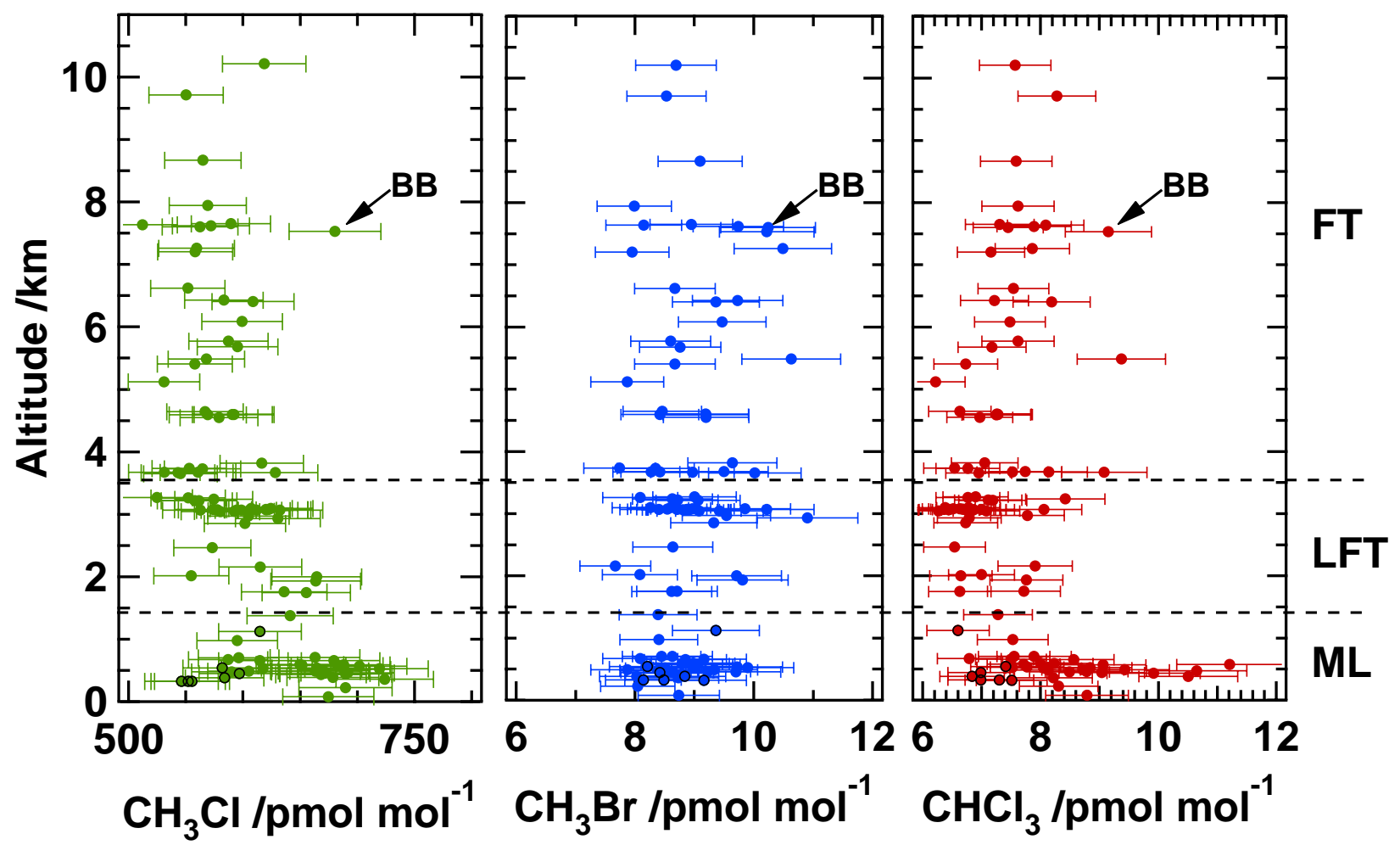

Fig. 4. Vertical distribution of $\mathrm{CH}_{3} \mathrm{Cl}, \mathrm{CH}_{3} \mathrm{Br}$ and $\mathrm{CHCl}_{3}$ (black circles mark the mixed layer samples at $\mathrm{TOL}=0 \mathrm{~h}$ ). The horizontal dashed lines mark the divisions referred to in the text as mixed layer (ML), lower free troposphere (LFT) and free troposphere (FT). BB marks the sample influenced by biomass burning.

in the ML $(<1660 \mathrm{~m})(n=35)$ are shown as a function of time over land (TOL) in Fig. 5.

The mixing ratios in the boundary layer ranged from 546 to 724 (avg 643) pmol $\mathrm{mol}^{-1}$ for $\mathrm{CH}_{3} \mathrm{Cl}, 6.6$ to 11.2 (avg 8.2) $\mathrm{pmol} \mathrm{mol}^{-1}$ for $\mathrm{CHCl}_{3}$ and 7.9 to 9.9 (avg 8.8) pmol mol ${ }^{-1}$ for $\mathrm{CH}_{3} \mathrm{Br}$. These are somewhat higher than the global mean value of $550 \pm 30 \mathrm{pmol} \mathrm{mol}^{-1}$ for $\mathrm{CH}_{3} \mathrm{Cl}$, which is expected since generally higher concentrations are reported for lower latitudes (WMO, 2007b). For $\mathrm{CHCl}_{3}$, the values reported here agree very well with the average mixing ratio for the $\mathrm{SH}$ tropics, $9.7 \mathrm{pmol} \mathrm{mol}^{-1}$ (Khalil and Rasmussen, 1999). For $\mathrm{CH}_{3} \mathrm{Br}$ the measured range fits the global average $7.9 \mathrm{pmol} \mathrm{mol}^{-1}$ (Simmonds et al., 2004). The error bars shown in Fig. 5 indicate the total uncertainty of the individual measurements $\left( \pm 5.9 \%\right.$ for $\mathrm{CH}_{3} \mathrm{Cl}, \pm 7.8 \%$ for $\mathrm{CH}_{3} \mathrm{Br}$ and $\pm 8.0 \%$ for $\mathrm{CHCl}_{3}$ ).

To calculate the time the air parcel spent over land we used the following approach. Starting at the sampling position we followed the path of the air parcel along the back trajectory in distinct time steps until it reached the coastline. For this procedure we used 10-day back trajectories, provided by P. van Velthoven (Royal Netherlands Meteorological Institute (KNMI), De Bilt, Netherlands). Trajectories were calculated using the KNMI trajectory model TRAJKS based on 6 hourly ECMWF three-dimensional meteorologi- cal wind fields, interpolated to a $1^{\circ} \times 1^{\circ}$ lat-lon grid.

The uncertainty associated with the trajectories is highly dependent on the employed meteorological parameters. The general weather situation in the region is quite invariant (trade wind zone) and not more than the first $48 \mathrm{~h}$ of the calculated trajectories are considered for TOL calculation. Nevertheless, to account for the uncertainty in the trajectories we have applied an error of $\pm 2 \mathrm{~h}$ for TOL. For the reasons stated above we feel that the trajectories can be used in this case to estimate our TOL with reasonable accuracy. Furthermore, we consider this trajectory based method to be the best currently available to determine the time the air parcel spent over land.

Samples taken above the ocean and coastline $(\mathrm{TOL}=0 \mathrm{~h}$ ) consisted of marine air and are used to define the boundary conditions, e.g. start mixing ratio prior to accumulation of compounds emitted from the forest. Mixed layer samples at TOL $=0 \mathrm{~h}$ are encircled in black in Fig. 4. In general there is no significant difference between ocean and coastline mixing ratios. For $\mathrm{CH}_{3} \mathrm{Cl}$ and $\mathrm{CHCl}_{3}$ four data points at low TOL appear as outliers to the fit (marked with a black asterisks in Figs. 1 and 5). Interestingly, these samples were taken in somewhat different geographical circumstances than the rest of the dataset. The sample taken at $0 \mathrm{~h}$ TOL was deliberately collected at low altitude (200 m a.s.1.) directly 

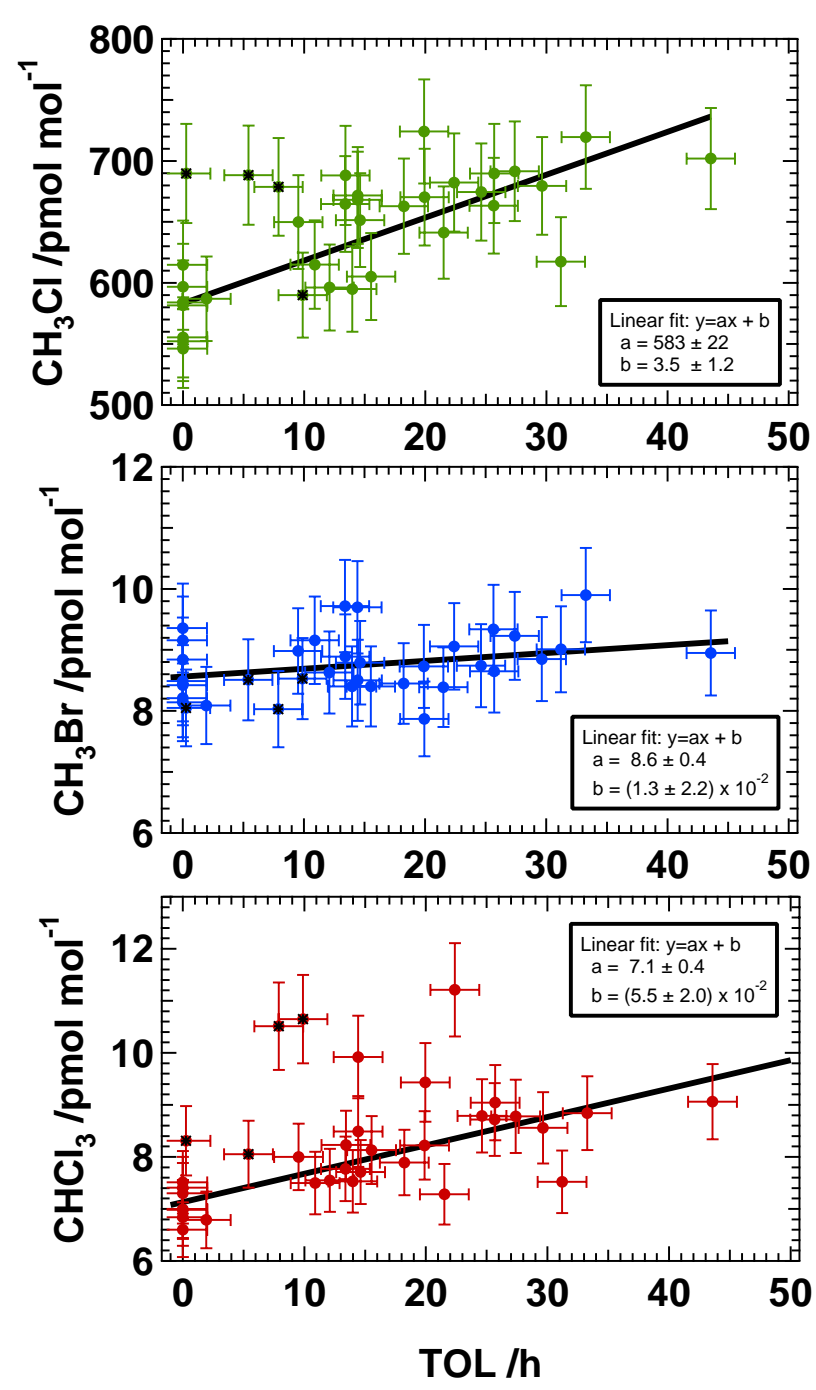

Fig. 5. Mixing ratios of $\mathrm{CH}_{3} \mathrm{Cl}, \mathrm{CH}_{3} \mathrm{Br}$ and $\mathrm{CHCl}_{3}$ vs. TOL. Dots represent the mixed layer samples with their individual error bars. The black line indicates the regression line. Fit coefficients including their uncertainty are given in the boxes; black asterisks mark samples excluded from the calculation.

above coastal salt marshes as such regions have been suggested to emit $\mathrm{CH}_{3} \mathrm{Cl}$ (Rhew et al., 2000), although this view was recently questioned (Wang et al., 2006). The three samples at 5, 8 and $10 \mathrm{~h}$ TOL were taken in the vicinity of the capital of French Guyana, Cayenne, downwind of Rochambeau airport and were therefore probably influenced by anthropogenic emissions. For the aforementioned reasons these points are not included in the flux calculations given below.

An orthogonal distance regression was used to calculate the net flux from the rainforest ecosystem. Rather than minimizing the sum of squared errors this method minimizes the orthogonal distance from the data to the fitted curve. The slope of the fit gives the increase of the mixing ratio per hour the air mass spent over the jungle. The black line in Fig. 5 indicates the regression line, while fit coefficients including their uncertainty (equivalent to $2 \sigma$ ) are given in the boxes. To calculate the fit coefficients and their confidence parameters, the total uncertainty of each individual data point (regarding mixing ratio and TOL) was used as weighting parameter. In this case the flux was statistically significant if the given deviation was not bigger than the value of the parameter itself. Two compounds showed a significant correlation with TOL $\left(\Delta \mathrm{CH}_{3} \mathrm{Cl} / \Delta \mathrm{TOL}=3.5 \pm 1.2(2 \sigma) \mathrm{pmol} \mathrm{mol}^{-1} \mathrm{~h}^{-1}\right.$ and $\left.\Delta \mathrm{CHCl}_{3} / \Delta \mathrm{TOL}=(5.5 \pm 2.0) \times 10^{-2}(2 \sigma) \mathrm{pmol} \mathrm{mol}^{-1} \mathrm{~h}^{-1}\right)$ and thus appear to be emitted from the forest. For $\mathrm{CH}_{3} \mathrm{Br}$ the slope is not significant $\left(\Delta \mathrm{CH}_{3} \mathrm{Br} / \Delta \mathrm{TOL}=(1.3 \pm 2.2) \times 10^{-2}\right.$ $(2 \sigma) \mathrm{pmol} \mathrm{mol}^{-1} \mathrm{~h}^{-1}$ ) and therefore no net flux could be determined within our detection limit.

Using the slope derived from Fig. 5 the flux was calculated by following formula:

$F=(\Delta \mathrm{MR} / \Delta \mathrm{TOL}) \times \mathrm{H}_{M L} \times(p \times M /(R \times T))$

Where $F$ is the flux $\left(\mu \mathrm{g} \mathrm{m}^{-2} \mathrm{~h}^{-1}\right), \Delta \mathrm{MR} / \Delta \mathrm{TOL}$ the linear regression slope ( $\left.\mathrm{pmol} \mathrm{mol}^{-1} \mathrm{~h}^{-1}\right), \mathrm{H}_{M L}$ the mean mixing layer height $(1400 \pm 260 \mathrm{~m}(2 \sigma)(n=11)), p$ the mean air pressure below $1660 \mathrm{~m}(941 \pm 71 \mathrm{hPa}(2 \sigma)(n=34710)), M$ the molar weight $(\mu \mathrm{g}), R$ the gas constant $\left(0.08314 \mathrm{hPa} \mathrm{m}^{3} \mathrm{~K}^{-1}\right)$ and $T$ the mean air temperature below $1660 \mathrm{~m}(296 \pm 15 \mathrm{~K}$ $(2 \sigma)(n=33596))$.

The result is a flux of $9.5( \pm 3.82 \sigma) \mu \mathrm{g} \mathrm{CH}_{3} \mathrm{Cl} \mathrm{m}^{-2} \mathrm{~h}^{-1}$ and $0.35( \pm 0.152 \sigma) \mu \mathrm{g} \mathrm{CHCl}_{3} \mathrm{~m}^{-2} \mathrm{~h}^{-1}$, respectively. Using the slope uncertainty of $\Delta \mathrm{CH}_{3} \mathrm{Br} / \Delta \mathrm{TOL}$ we determine the lowest detectable $\mathrm{CH}_{3} \mathrm{Br}$ flux as $0.11(2 \sigma) \mu \mathrm{g}$ $\mathrm{CH}_{3} \mathrm{Br} \mathrm{m}^{-2} \mathrm{~h}^{-1}$.

Despite their large size and potential importance to atmospheric chemistry, the Earth's tropical forests are surprisingly poorly characterized for organohalogen species. There are only few measurement studies available for comparison and these were mainly performed in Asia (Li et al., 1999; Yokouchi et al., 2000; Yokouchi et al., 2002; Saito and Yokouchi, 2006; Yokouchi et al., 2007) measured in a tropical glasshouse and on forested islands. Scheeren et al. (2003) measured the two chlorinated compounds in Suriname in March 1998 and Moore et al. (2005) analyzed tropical fungi and soils in Brazil.

Li et al. (1999) observed a very high flux of 41 to $64 \mu \mathrm{g} \mathrm{CH}_{3} \mathrm{Cl} \mathrm{m}^{-2} \mathrm{~h}^{-1}$ from a coastal area at Okinawa Island, Japan. Yokouchi et al. (2002) reported an flux of 5.4 (3.8-8) $\mu \mathrm{g} \mathrm{CH}_{3} \mathrm{Cl} \mathrm{m}^{-2} \mathrm{~h}^{-1}$ from a greenhouse containing vegetation typical of the lowland tropical forest of Southeast Asia and smaller though not quantified fluxes of $\mathrm{CH}_{3} \mathrm{Br}$ and $\mathrm{CH}_{3} \mathrm{I}$. Recently they reported an emission rate of 12 $33 \mu \mathrm{g} \mathrm{CH}_{3} \mathrm{Cl} \mathrm{m}^{-2} \mathrm{~h}^{-1}$ measured on one of the subtropical Okinawa islands (Yokouchi et al., 2007). The study performed by Scheeren et al. (2003) over Suriname in March 1998 reported fluxes of $7.6 \pm 1.8 \mu \mathrm{g} \mathrm{CH}_{3} \mathrm{Clm}^{-2} \mathrm{~h}^{-1}$ and $1.1 \pm 0.08 \mu \mathrm{g} \mathrm{CHCl}_{3} \mathrm{~m}^{-2} \mathrm{~h}^{-1}$. Moore et al. (2005) reported wood rotting fungi to be a $\mathrm{CH}_{3} \mathrm{Cl}$ source and confirmed the 
soil as a sink, in agreement with previous measurements (Watling and Harper, 1998; Khalil and Rasmussen, 2000). Elevated mixing ratios above the canopy led them to the assumption that there have to be further strong sources in the rainforest beside the fungi.

The $\mathrm{CH}_{3} \mathrm{Cl}$ fluxes of Scheeren et al. (2003) agree very well with the $9.5( \pm 3.82 \sigma) \mu \mathrm{g} \mathrm{CH}_{3} \mathrm{Cl} \mathrm{m}^{-2} \mathrm{~h}^{-1}$ derived in this study, although these results were obtained using a different measurement technique (GC-ECD). The fluxes derived by Yokouchi et al. (2002) and Yokouchi et al. (2007) are in the same range, although they were obtained surveying a different kind of tropical species in Southeast Asia, whereas the study of Li et al. (1999) is reporting much higher fluxes than all other studies. However, the latter value was obtained in a coastal area and might be influenced by coastal/marine production. It is included here for completeness, but is not expected to match the other vegetation focused studies.

These findings support previous model results (Lee-Taylor et al., 2001; Yoshida et al., 2004 and Yoshida et al., 2006), which have postulated a land based, constant source of $\mathrm{CH}_{3} \mathrm{Cl}$ all over the tropics.

In the case of $\mathrm{CHCl}_{3}$ there is to our knowledge only one comparable flux reported in literature. Scheeren et al. (2003) obtained a value approximately three times higher in March 1998 than the one measured in our study during October 2005. There are two wet seasons in Suriname associated with the passage of the ITCZ over the country. These wet seasons are bracketed by two dry seasons, one from February to April termed the short dry season, and one from August to November, the long dry season. Thus, both available fluxes were determined in dry seasons and therefore only small differences in the meteorological conditions were observed between the March and October field campaigns. The precipitation and therefore presumably soil moisture were very similar (70.3 mm during March 1998, 65.6 mm in October 2005), whereas the maximum temperature was on average higher by $1.6^{\circ} \mathrm{C}$ in October $2005\left(33.4^{\circ} \mathrm{C}\right)$, while the minimum temperature was similar $\left(23.6^{\circ} \mathrm{C}\right.$ March $1998,23.8^{\circ} \mathrm{C}$ October 2005) (C. Becker, Meteorological Service Suriname, personal communication). Meteorological parameters therefore do not provide a good explanation for the discrepancy between the two measurements.

However, the results presented here show strong differences in the $\mathrm{CHCl}_{3}$ flux but at most very small differences in the $\mathrm{CH}_{3} \mathrm{Cl}$ emissions. This leads to the assumption that these compounds are emitted via different formation pathways.

To investigate this discrepancy in detail one has to give up on the wide view of the ecosystem as a whole. We have to consider the different parts of the rainforest and thereby a multitude of interacting sinks and sources, e.g. soil, decaying leaves, fungi and the plants themselves.

Not regarding the anthropogenic, oceanic and biomass burning sources of $\mathrm{CH}_{3} \mathrm{Cl}$ and $\mathrm{CHCl}_{3}$ several further possible formation pathways have been reported. Isidorov et al. (1985) and Isidorov and Jdanova (2002) showed that
$\mathrm{CH}_{3} \mathrm{Cl}$ as well as $\mathrm{CHCl}_{3}$ are emitted by living leaves and leaf litter of some tree species (e.g. pencil cedar, evergreen cypress, northern white cedar, aspen and willow). Other higher plants such as tropical ferns, halophytes and potato tubers show significant emissions of $\mathrm{CH}_{3} \mathrm{Cl}$ (Harper et al., 1999; Rhew et al., 2000; Yokouchi et al., 2002; Harper et al., 2003) as well as fungi (Watling and Harper, 1998).

Although there is some evidence that $\mathrm{CHCl}_{3}$ is emitted directly by plants (Isidorov et al., 1985), soil processes are assumed to be the major source in the tropical ecosystem (Laturnus et al., 2002; McCulloch, 2003, see Table 1). Several pathways are reported in the literature: Basidiomycetous fungi are able to synthesize $\mathrm{CHCl}_{3}$ de novo (Hoekstra et al., 1998a). It can also be formed by chlorination of organic matter catalysed by extracellular peroxidase-like enzymes (chloroperoxydase CPO) most probably deriving from fungi (Hoekstra et al., 1998b). Another plausible mechanism is the decarboxylation of trichloroacetic acid (Frank et al., 1989; Haselmann et al., 2000a).

The metabolic origin of $\mathrm{CH}_{3} \mathrm{Cl}$ has been identified as an enzyme catalysed halide methylation reaction, which uses either S-adenosyl-methionine (SAM) or methionine as a methyl donor (Harper et al., 1999; Harper, 2000). Hamilton et al. (2003) showed that abiotic chloride methylation by plant pectin is an efficient, environmentally significant process producing $\mathrm{CH}_{3} \mathrm{Cl}$. Chloride ions, which are plentiful in the leaf, react with pectin during leaf senescence and an abiotic substitution reaction yields $\mathrm{CH}_{3} \mathrm{Cl}$. This mechanism could account for the $\mathrm{CH}_{3} \mathrm{Cl}$ release from leaf litter and during biomass burning. Recent results from isotopic studies of $\mathrm{CH}_{3} \mathrm{Cl}$ (Keppler et al., 2005) support this abiotic mechanism. Another abiotic process forming monohalogenated alkanes was identified by Keppler et al. (2000). During the oxidation of organic matter by an electron acceptor like Fe (III) in soil, sediments or organic rich waters halide ions are methylated or even build ethyl or propyl halides.

While the aforementioned substitution mechanisms can efficiently produce monohalogenated compounds there are not likely to be the source of the $\mathrm{CHCl}_{3}$, which would require multiple substitution. The fact that the two molecules do not show the same variation in their emissions strengthens the assumption that they are produced via different production pathways.

In summary it thus appears that the $\mathrm{CH}_{3} \mathrm{Cl}$ and $\mathrm{CHCl}_{3}$ are produced at different locations and by different mechanisms. $\mathrm{CH}_{3} \mathrm{Cl}$ is produced mainly by plants themselves and during their decay abiotically or by fungi. Whereas main $\mathrm{CHCl}_{3}$ production is restricted to fungal and microbial processes within the soil and leaf litter.

Measurements of soils in temperate forests indicate $\mathrm{CHCl}_{3}$ emissions of up to $0.34 \mu \mathrm{g} \mathrm{m}^{-2} \mathrm{~h}^{-1}$ from soils covered with woodchips (Hoekstra et al., 2001). Haselmann et al. (2000b) report local emissions in a Danish forest up to $0.16 \mu \mathrm{g}$ $\mathrm{m}^{-2} \mathrm{~h}^{-1}$. These rates correspond very well with the flux of $0.35( \pm 0.152 \sigma) \mu \mathrm{g} \mathrm{m}^{-2} \mathrm{~h}^{-1} \mathrm{CHCl}_{3}$ derived in this study and 
strengthens the argument that the main fraction of $\mathrm{CHCl}_{3}$ in the tropical ecosystem is produced by soil processes. This would support the assumption of Laturnus et al. (2002), who speculated on a similar or even larger input from tropical forest areas as reported from northern temperate forests.

Regarding $\mathrm{CH}_{3} \mathrm{Br}$ the average mixing ratios reported here are slightly elevated compared to global background values (WMO, 2007b), but no significant net emission from the rainforest of $\mathrm{CH}_{3} \mathrm{Br}$ could be determined. This is in contrast to greenhouse and small scale experiments (Gan et al., 1998; Yokouchi et al., 2002; Saito and Yokouchi, 2006), which report $\mathrm{CH}_{3} \mathrm{Br}$ emission from plants of the brassicaceae family, Asian lowland forest and tropical ferns. A vegetation source providing additional $45.6 \mathrm{Gg} \mathrm{yr}^{-1}$ in the tropics as postulated by Warwick et al. (2006) would correspond to a local gross flux of $0.287 \mu \mathrm{g} \mathrm{CH}_{3} \mathrm{Br} \mathrm{m}^{-2} \mathrm{~h}^{-1}$. An emission of this order of magnitude would have been detected by this study (detection limit for $\mathrm{CH}_{3} \mathrm{Br}: 0.11 \mu \mathrm{g} \mathrm{m}^{-2} \mathrm{~h}^{-1}$ ). Since soils are known to uptake $\mathrm{CH}_{3} \mathrm{Br}$ (see Table 1), one may speculate that the possible release from tropical vegetation is reduced by a local soil sink and therefore not detectable in a large scale experiment like this one. On the other hand, a recent modelling study suggests that the atmospheric lifetime of $\mathrm{CH}_{3} \mathrm{Br}$ has been underestimated (Kerkweg et al., 2008), which also closes the imbalance between sources and sinks without the presumed vegetation source.

\subsection{Global emissions from the tropical forest}

Before extrapolating the observed net fluxes from the South American rainforest to the global scale several aspects must be noted.

Firstly, the fluxes measured here were the net effect of the "rainforest ecosystem" at one time of year. As mentioned previously there are likely several competing sources and sinks (plants, bacteria, fungi, senescencing leaves etc.) within the ecosystem each of which may vary independently in the course of a year.

Secondly, the tropical forest covers a large fraction of the globe and accounts for nearly half of the total global forest (FAO, 2001). The largest areas are found in the Amazon Basin (South America) and the Congo Basin (Africa), as well as large parts of Southeast Asia and Oceania are covered by tropical forest. For these extrapolations, the forest from these diverse regions is considered homogenous. This is obviously a simplification and therefore the derived fluxes should be regarded as a rough estimate.

Thirdly, the definition of the forest area is an important issue. Using the widely distributed number of 18.2 million $\mathrm{km}^{2}$ of tropical forest (FAO, 2001), which refers to all kinds of forest located in the tropics, we obtained fluxes of $1.5( \pm 0.6$ $2 \sigma) \mathrm{Tg} \mathrm{CH}_{3} \mathrm{Cl} \mathrm{yr}^{-1}$ and $56( \pm 232 \sigma) \mathrm{Gg} \mathrm{CHCl}_{3} \mathrm{yr}^{-1}$. Using the lowest detectable flux derived in Sect. 3.4 we determine the lowest global detectable $\mathrm{CH}_{3} \mathrm{Br}$ flux to be 17

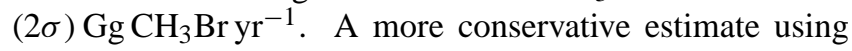

only the area of tropical rainforest (10.8 million $\mathrm{km}^{2}$ ) (FAO, $2001)$, results in fluxes of $0.9( \pm 0.42 \sigma) \mathrm{Tg} \mathrm{CH}_{3} \mathrm{Cl} \mathrm{yr}^{-1}$ and $33( \pm 142 \sigma) \mathrm{Gg} \mathrm{CHCl}_{3} \mathrm{yr}^{-1}$.

These numbers are obtained using the flux derived by this study throughout the year. Bearing in mind that $\mathrm{CHCl}_{3}$ emissions seem to be varying and other studies reported higher flux rates, one should regard these flux estimates as a lower limit. Taking into account the measurements of Scheeren et al. (2003) - which were carried out in the same region - and using the average flux of both studies, the annual emission of $\mathrm{CHCl}_{3}$ would be more than doubled. It should be noted that this estimate is particularly uncertain since no measurements have yet been made in the wet season.

Although these extrapolations are inherently uncertain due to the aforementioned assumptions in the calculation, they do represent our current best estimate of the rainforest contribution to the global budgets of these compounds and appear to be quite reasonable. The calculated flux of $1.5( \pm 0.6$ $2 \sigma) \mathrm{Tg} \mathrm{CH}_{3} \mathrm{Cl} \mathrm{yr}^{-1}$ from the tropical forest would account for half of the additional source postulated by the models (Lee-Taylor et al., 2001; Yoshida et al., 2006). In comparison with the current best estimates of global tropical source terms, it is at the lower end of the range reported ( 0.82 to $8.2 \mathrm{Tg} \mathrm{yr}^{-1}$ from tropical plants, 0.03 to $2.5 \mathrm{Tg} \mathrm{yr}^{-1}$ from senescent/dead leaves and a sink of 0.1 to $1.6 \mathrm{Tg} \mathrm{yr}^{-1}$ by soil uptake). Nevertheless an emission of this order of magnitude would be the main global source for $\mathrm{CH}_{3} \mathrm{Cl}$, exceeding the ocean, biomass burning and anthropogenic sources. It should be noted that the studies providing the basis for current estimates (Yokouchi et al., 2002 and Hamilton et al., 2003) were restricted to the small scale (greenhouse or laboratory measurements), and therefore the large-scale approach applied here should be a more reliable assessment of the real global net flux from this ecosystem.

The $\mathrm{CHCl}_{3}$ flux extrapolated to all tropical forests results in a net flux of $56( \pm 232 \sigma) \mathrm{Gg} \mathrm{yr}^{-1}$. This is between 5 and $10 \%$ of the total sources, and as previously mentioned, it could be already incorporated in the soil source term.

The global extrapolation of the lowest detectable $\mathrm{CH}_{3} \mathrm{Br}$ flux yields $17(2 \sigma) \mathrm{Gg} \mathrm{yr}^{-1}$. A source of this size would be a non-negligible contribution to the global budget, supplying between 6 and $22 \%$ of the total global sources.

Once again it is important to recall that the global fluxes presented in this study are net sources. To compare them with the numbers listed in Table 1 all possible sinks and sources within the measurement area have to be combined.

To better understand the budgets of these compounds it will be necessary to examine seasonal variations of the various sources and sinks within the rainforest ecosystem. In particular, the driving parameters of the sources and sinks need to be better characterized, e.g. their dependence on ambient temperature and/or soil moisture changes. These variations will be particularly important for predicting future changes in the natural halocarbon emissions fluxes, which will become more important as the anthropogenic contribution recedes. 


\section{Summary and conclusions}

This study presents airborne measurements of $\mathrm{CH}_{3} \mathrm{Cl}$, $\mathrm{CHCl}_{3}$ and $\mathrm{CH}_{3} \mathrm{Br}$ over the tropical rainforest of Suriname. Aircraft measurements of the kind reported here inherently consider the rainforest ecosystem as a whole, and are ideally suited to gauge the net effect over large areas. The fluxes are possibly the result of separate strong sinks and strong sources within the ecosystem, and represent the net flux from the rainforest to the atmosphere in October 2005. For both $\mathrm{CH}_{3} \mathrm{Cl}$ and $\mathrm{CHCl}_{3}$ a significant correlation between mixing ratio and time the air mass spent over the rainforest was found. The rainforest ecosystem produced $9.5( \pm 3.8$ $2 \sigma) \mu \mathrm{g} \mathrm{m}^{-2} \mathrm{~h}^{-1} \mathrm{CH}_{3} \mathrm{Cl}$ and $0.35( \pm 0.152 \sigma) \mu \mathrm{g} \mathrm{m}^{-2} \mathrm{~h}^{-1}$ $\mathrm{CHCl}_{3}$.

No significant trend for $\mathrm{CH}_{3} \mathrm{Br}$ could be determined from these measurements. The tropical vegetation gross source postulated by an inverse model prediction (Warwick et al., 2006) is most probably reduced to a very small net flux by concomitant sinks like soil uptake and photolysis. Our measurements over the South American rainforest agree with global observations, and vertical gradients between the boundary layer and free troposphere appear to be small or absent. This supports the conclusion that tropical forest ecosystem is not a significant net global $\mathrm{CH}_{3} \mathrm{Br}$ source.

The $\mathrm{CH}_{3} \mathrm{Cl}$ flux is in good agreement with previously measured fluxes by Yokouchi et al. (2002) and Yokouchi et al. (2007), who reported 5.4 (3.8-8) $\mu \mathrm{g} \mathrm{CH}_{3} \mathrm{Cl} \mathrm{m}^{-2} \mathrm{~h}^{-1}$ and $12-33 \mu \mathrm{g} \mathrm{CH}_{3} \mathrm{Cl} \mathrm{m}^{-2} \mathrm{~h}^{-1}$ for Asian lowland tropical forest, and Scheeren et al. (2003), who derived $7.6( \pm 1.8) \mu \mathrm{g}$ $\mathrm{CH}_{3} \mathrm{Cl} \mathrm{m}^{-2} \mathrm{~h}^{-1}$ over Suriname. This suggests that the rainforest ecosystem appears to be a fairly consistent and important $\mathrm{CH}_{3} \mathrm{Cl}$ source in the tropics. Extrapolating the flux to the global scale resulted in $1.5( \pm 0.62 \sigma) \mathrm{Tg} \mathrm{CH}_{3} \mathrm{Cl} \mathrm{yr}^{-1}$, which would account for half the additional tropical source postulated by the previous model studies (Lee-Taylor et al., 2001; Yoshida et al., 2006). Since the soil is known to be a sink for $\mathrm{CH}_{3} \mathrm{Cl}$ the observed total flux in this study should be considered as lower limit of the possible direct production by plants or plant decay. It ranges at the lower end of current best estimates of the global tropical source terms but nevertheless it would be the main global source.

Regarding the $\mathrm{CHCl}_{3}$ emission we observed a threefold weaker flux than that derived by Scheeren et al. (2003). Our lower limit of the global extrapolated flux from the tropical forests is $56( \pm 232 \sigma) \mathrm{Gg} \mathrm{CHCl}_{3} \mathrm{yr}^{-1}$, about 5 to $10 \%$ of the total global sources. These fluxes may be incorporated in global models to provide an overall net source strength of the rainforest ecosystem. Since these numbers are based on a large scale approach local phenomena tend to be averaged out and a more representative value is obtained.

From the different emission patterns we conclude that these two compounds are probably produced via different mechanisms. According to the literature $\mathrm{CHCl}_{3}$ is most probably formed by microbial processes in the soil depend- ing on temperature and soil moisture, however, there are no clear meteorological differences between March 1998 and October 2005 to explain the flux differences observed. Performing a similar study during the wet season would provide additional information on the soil moisture dependence of the formation pathways and the seasonal variation of the emissions, which could be incorporated in global models.

To obtain a better understanding of the role of the rainforest ecosystem as a possible sink or source of halogenated organic species, more studies on the different tropical biomes are necessary. Furthermore, a more detailed survey of the possible contributors (plants, soil, leaf litter, fungi etc.) would complement the knowledge about the separate sources and sinks within the tropical rainforest ecosystem.

Acknowledgements. The authors like to thank the GABRIEL Team including the pilots and the Enviscope engineers. We appreciate the help of the Meteorological Service Suriname and the KNMI (Koninklijk Nederlands Meteorologisch Instituut) providing meteorological data, weather forecasts and air mass trajectories as well as the permission of Christian Gurk and Horst Fischer to make use of their CO and TOL data set. Special thanks to Bert Scheeren and Cor Becker for interesting and fruitful discussions. We are grateful to Elliot Atlas, University Miami for assistance with the calibration. Not least we like to thank Stefanie Wong-Zehnpfennig, Gunter Eerdekens and Heiko Bozem for their help.

Edited by: D. Helmig

\section{References}

Andreae, M. O. and Merlet, P.: Emission of trace gases and aerosols from biomass burning, Glob. Biogeochem. Cy., 15, 955-966, 2001.

Blake, N. J., Blake, D. R., Sive, B. C., Chen, T. Y., Rowland, F. S., Collins, J. E., Sachse, G. W., and Anderson, B. E.: Biomass burning emissions and vertical distribution of atmospheric methyl halides and other reduced carbon gases in the South Atlantic region, J. Geophys. Res.-Atmos., 101, 24 151-24 164, 1996.

Butler, J. H.: Atmospheric chemistry - Better budgets for methyl halides?, Nature, 403, 260-261, 2000.

Colomb, A., Williams, J., Crowley, J., Gros, V., Hofmann, R., Salisbury, G., Klupfel, T., Kormann, R., Stickler, A., Forster, C., and Lelieveld, J.: Airborne measurements of trace organic species in the upper troposphere over Europe: the impact of deep convection, Environ. Chem., 3, 244-259, 2006.

FAO: Forestry Paper 140: Global Forest Resources Assessment 2000 (FRA 2000), Food and Agricultural Organization of the United Nations, 1-149, Rome, Italy, 2001.

Frank, H., Frank, W., and Thiel, D.: $\mathrm{C}_{1}-$ and $\mathrm{C}_{2}$-Halocarbons in soil-air of forests, Atmos. Environ., 23, 1333-1335, 1989.

Gan, J., Yates, S. R., Ohr, H. D., and Sims, J. J.: Production of methyl bromide by terrestrial higher plants, Geophys. Res. Lett., 25, 3595-3598, 1998.

Gros, V., Williams, J., van Aardenne, J. A., Salisbury, G., Hofmann, R., Lawrence, M. G., von Kuhlmann, R., Lelieveld, J., Krol, M., 
Berresheim, H., Lobert, J. M., and Atlas, E.: Origin of anthropogenic hydrocarbons and halocarbons measured in the summertime european outflow (on Crete in 2001), Atmos. Chem. Phys., 3, 1223-1235, 2003,

http://www.atmos-chem-phys.net/3/1223/2003/.

Hamilton, J. T. G., McRoberts, W. C., Keppler, F., Kalin, R. M., and Harper, D. B.: Chloride methylation by plant pectin: An efficient environmentally significant process, Science, 301, 206209, 2003.

Harper, D. B., Harvey, B. M. R., Jeffers, M. R., and Kennedy, J. T.: Emissions, biogenesis and metabolic utilization of chloromethane by tubers of the potato (Solanum tuberosum), New Phytologist, 142, 5-17, 1999.

Harper, D. B.: The global chloromethane cycle: biosynthesis, biodegradation and metabolic role, Natural Product Reports, 17, 337-348, 2000.

Harper, D. B., Hamilton, J. T. G., Ducrocq, V., Kennedy, J. T., Downey, A., and Kalin, R. M.: The distinctive isotopic signature of plant-derived chloromethane: possible application in constraining the atmospheric chloromethane budget, Chemosphere, 52, 433-436, 2003.

Haselmann, K. F., Laturnus, F., Svensmark, B., and Gron, C.: Formation of chloroform in spruce forest soil - results from laboratory incubation studies, Chemosphere, 41, 1769-1774, 2000a.

Haselmann, K. F., Ketola, R. A., Laturnus, F., Lauritsen, F. R., and Gron, C.: Occurrence and formation of chloroform at Danish forest sites, Atmospheric Environment, 34, 187-193, $2000 \mathrm{~b}$.

Hoekstra, E. J., Verhagen, F. J. M., Field, J. A., De Leer, E. W. B., and Brinkman, U. A. T.: Natural production of chloroform by fungi, Phytochemistry, 49, 91-97, 1998a.

Hoekstra, E. J., De Leer, E. W. B., and Brinkman, U. A. T.: Natural formation of chloroform and brominated trihalomethanes in soil, Environmental Science \& Technology, 32, 3724-3729, 1998b.

Hoekstra, E. J., Duyzer, J. H., de Leer, E. W. B., and Brinkman, U. A. T.: Chloroform - concentration gradients in soil air and atmospheric air, and emission fluxes from soil, Atmospheric Environment, 35, 61-70, 2001.

Holton, J. R.: An Introduction to Dynamic Meteorology, 3rd ed., International Geophysics Series, edited by: Dmowska, R., and Holton, J. R., Academic Press, San Diego, 511 pp., 1992.

Isidorov, V. A., Zenkevich, I. G., and Ioffe, B. V.: Volatile Organic Compounds in the Atmosphere of Forests, Atmospheric Environment, 19, 1-8, 1985.

Isidorov, V. A. and Jdanova, M.: Volatile organic compounds from leaves litter, Chemosphere, 48, 975-979, 2002.

Keene, W. C., Khalil, M. A. K., Erickson, D. J., McCulloch, A., Graedel, T. E., Lobert, J. M., Aucott, M. L., Gong, S. L., Harper, D. B., Kleiman, G., Midgley, P., Moore, R. M., Seuzaret, C., Sturges, W. T., Benkovitz, C. M., Koropalov, V., Barrie, L. A., and Li, Y. F.: Composite global emissions of reactive chlorine from anthropogenic and natural sources: Reactive Chlorine Emissions Inventory, J. Geophys. Res.-Atmos., 104, 8429-8440, 1999.

Keppler, F., Eiden, R., Niedan, V., Pracht, J., and Scholer, H. F.: Halocarbons produced by natural oxidation processes during degradation of organic matter, Nature, 403, 298-301, 2000.

Keppler, F., Harper, D. B., Rockmann, T., Moore, R. M., and Hamilton, J. T. G.: New insight into the atmospheric chloromethane budget gained using stable carbon isotope ratios, Atmos. Chem.
Phys., 5, 2403-2411, 2005,

http://www.atmos-chem-phys.net/5/2403/2005/.

Kerkweg, A., Jöckel, P., Warwick, N., Gebhardt, S., Brenninkmeijer, C. A. M., and Lelieveld, J.: Consistent simulation of bromine chemistry from the marine boundary layer to the stratosphere, Part II: Bromocarbons, Atmos. Chem. Phys. Discuss., 8, 94779530, 2008,

http://www.atmos-chem-phys-discuss.net/8/9477/2008/.

Khalil, M. A. K., and Rasmussen, R. A.: Atmospheric chloroform, Atmospheric Environment, 33, 1151-1158, 1999.

Khalil, M. A. K. and Rasmussen, R. A.: Soil-atmosphere exchange of radiatively and chemically active gases, Environ. Sci. Poll. Res., 7, 79-82, 2000.

Krejci, R., Strom, J., de Reus, M., Williams, J., Fischer, H., Andreae, M. O., and Hansson, H. C.: Spatial and temporal distribution of atmospheric aerosols in the lowermost troposphere over the Amazonian tropical rainforest, Atmos. Chem. Phys., 5, 1527-1543, 2005, http://www.atmos-chem-phys.net/5/1527/2005/.

Laturnus, F., Haselmann, K. F., Borch, T., and Gron, C.: Terrestrial natural sources of trichloromethane (chloroform, $\left.\mathrm{CHCl}_{3}\right)-\mathrm{An}$ overview, Biogeochemistry, 60, 121-139, 2002.

Lee-Taylor, J. M., Doney, S. C., Brasseur, G. P., and Muller, J. F.: A global three-dimensional atmosphere-ocean model of methyl bromide distributions, J. Geophys. Res.-Atmos., 103, $16039-$ 16057, 1998.

Lee-Taylor, J. M., Brasseur, G. P., and Yokouchi, Y.: A preliminary three-dimensional global model study of atmospheric methyl chloride distributions, J. Geophys. Res.-Atmos., 106, $34221-$ 34 233, 2001.

Lelieveld, J., Butler, T. M., Crowley, J. N., Dillon, T. J., Fischer, H., Ganzeveld, L., Harder, H., Lawrence, M. G., Martinez, M., Taraborelli, D., and Williams, J.: Atmospheric oxidation capacity sustained by a tropical forest, Nature, 452, 737-740, doi:10.1038/nature06870, 2008.

Levine, J. G., Braesicke, P., Harris, N. R. P., Savage, N. H., and Pyle, J. A.: Pathways and timescales for troposphere-tostratosphere transport via the tropical tropopause layer and their relevance for very short lived substances, J. Geophys. Res.Atmos., 112, D04308. doi:10.1029/2005JD006940, 2007.

Li, H. J., Yokouchi, Y., and Akimoto, H.: Measurement of methyl halides in the marine atmosphere, Atmospheric Environment, 33, 1881-1887, 1999.

Lobert, J. M., Keene, W. C., Logan, J. A., and Yevich, R.: Global chlorine emissions from biomass burning: Reactive Chlorine Emissions Inventory, J. Geophys. Res.-Atmos., 104, 8373-8389, 1999.

Mak, J. E. and Brenninkmeijer, C. A. M.: Compressed-Air Sample Technology for Isotopic Analysis of Atmospheric CarbonMonoxide, J. Atmos. Ocean. Technol., 11, 425-431, 1994.

McCulloch, A.: Chloroform in the environment: occurrence, sources, sinks and effects, Chemosphere, 50, 1291-1308, 2003.

Moore, R. M., Gut, A., and Andreae, M. O.: A pilot study of methyl chloride emissions from tropical woodrot fungi, Chemosphere, 58, 221-225, 2005.

O’Doherty, S., Simmonds, P. G., Cunnold, D. M., Wang, H. J., Sturrock, G. A., Fraser, P. J., Ryall, D., Derwent, R. G., Weiss, R. F., Salameh, P., Miller, B. R., and Prinn, R. G.: In situ chloroform measurements at Advanced Global Atmospheric Gases Experi- 
ment atmospheric research stations from 1994 to 1998, J. Geophys. Res.-Atmos., 106, 20 429-20 444, 2001.

Reeves, C. E.: Atmospheric budget implications of the temporal and spatial trends in methyl bromide concentration, J. Geophys. Res.-Atmos., 108, 4343, doi:10.1029/2002JD002943, 2003.

Rhew, R. C., Miller, B. R., and Weiss, R. F.: Natural methyl bromide and methyl chloride emissions from coastal salt marshes, Nature, 403, 292-295, 2000.

Saito, T. and Yokouchi, Y.: Diurnal variation in methyl halide emission rates from tropical ferns, Atmos. Environ., 40, 2806-2811, 2006.

Scheeren, H. A., Lelieveld, J., Williams, J., Fischer, H., and Warneke, C.: Measurement of reactive chlorocarbons over the Surinam tropical rain forest: indications for strong biogenic emissions, Atmos. Chem. Phys. Discuss., 3, 5469-5512, 2003, http://www.atmos-chem-phys-discuss.net/3/5469/2003/.

Simmonds, P. G., Derwent, R. G., Manning, A. J., Fraser, P. J., Krummel, P. B., O’Doherty, S., Prinn, R. G., Cunnold, D. M., Miller, B. R., Wang, H. J., Ryall, D. B., Porter, L. W., Weiss, R. F., and Salameh, P. K.: AGAGE observations of methyl bromide and methyl chloride at Mace Head, Ireland, and Cape Grim, Tasmania, 1998-2001, J. Atmos. Chem., 47, 243-269, 2004.

Stickler, A., Fischer, H., Bozem, H., Gurk, C., Schiller, C., Martinez-Harder, M., Kubistin, D., Harder, H., Williams, J., Eerdekens, G., Yassaa, Y., Ganzeveld, L., Sander, R., and Lelieveld, J.: Chemistry, transport and dry deposition of trace gases in the boundary layer over the tropical Atlantic Ocean and the Guyanas during the GABRIEL field campaign, Atmos. Chem. Phys. 7, 3933-3956, 2007.

Stolarski, R. S. and Cicerone, R. J.: Stratospheric Chlorine: a Possible Sink for Ozone, Canadian Journal of Chemistry, 52, 1610 1615, doi:10.1139/v78-233, 1974.

Thompson, T. M., Butler, J. H., Daube, B. C., Dutton, G. S., Elkins, J. W., Hall, B. D., Hurst, D. F., King, D. B., Kline, E. S., LaFleur, B. G., Lind, J., Lovitz, S., Mondeel, D. J., Montzka, S. A., Moore, F. L., Nance, J. D., Neu, J. L., Romashkin, P. A., Scheffer, A., and Snible, W. J.: Halocarbons and other atmospheric trace species, in Climate Monitoring and Diagnostics Laboratory: Summary Report 27 2002-2003, edited by: Schnell, R. C., Buggle, A.-M., and Rosson, R. M., 115-135, NOAA/Climate Monitoring and Diagnostics Laboratory, Boulder, Colo. Available: http://www.esrl.noaa.gov/gmd/ publications/annrpt27/hats5.pdf, 2004.

Trudinger, C. M., Etheridge, D. M., Sturrock, G. A., Fraser, P. J., Krummel, P. B., and McCulloch, A.: Atmospheric histories of halocarbons from analysis of Antarctic firn air: Methyl bromide, methyl chloride, chloroform, and dichloromethane, J. Geophys. Res.-Atmos., 109, D22310, doi:10.1029/2004JD004932, 2004.

Wang, J. X., Li, R. J., Guo, Y. Y., Qin, P., and Sun, S. C.: The flux of methyl chloride along an elevational gradient of a coastal salt marsh, Eastern China, Atmos. Environ., 40, 6592-6605, 2006.

Warwick, N. J., Pyle, J. A., and Shallcross, D. E.: Global modelling of the atmospheric methyl bromide budget, J. Atmos. Chem., 54, 133-159, 2006.
Watling, R. and Harper, D. B.: Chloromethane production by woodrotting fungi and an estimate of the global flux to the atmosphere, Mycological Research, 102, 769-787, 1998.

Williams, J., Yassaa, N., Bartenbach, S., and Lelieveld, J.: Mirror image hydrocarbons from Tropical and Boreal forests, Atmos. Chem. Phys., 7, 973-980, 2007, http://www.atmos-chem-phys.net/7/973/2007/.

WMO: Scientific Assessment of Ozone Depletion: 1998, Chapter 2: Short-Lived Ozone-Related Compounds, Global Ozone Research and Monitoring Project - Report No. 44, World Meteorological Organization, 2.1-2.56, Geneva, Switzerland, 1999.

WMO: Scientific Assessment of Ozone Depletion: 2002, Chapter 1: Controlled Substances and Other Source Gases, Global Ozone Research and Monitoring Project - Report No. 47, World Meterological Organization, 1.1-1.83, Geneva, Switzerland, 2003.

WMO: Scientific Assessment of Ozone Depletion: 2006, Chapter 8: Halocarbon Scenarios, ODPs ans GWPs, Global Ozone Research and Monitoring Project - Report No. 50, World Meteorological Organization, 8.1-8.39, Geneva, Switzerland, 2007a.

WMO: Scientific Assessment of Ozone Depletion: 2006, Chapter 1: Long-Lived Compounds, Global Ozone Research and Monitoring Project - Report No. 50, World Meteorological Organization, 1.1-1.63, Geneva, Switzerland 2007b.

Wofsy, S. C., McElroy, M. B., and Yung, Y. L.: Chemistry of Atmospheric Bromine, Geophysical Research Letters, 2, 215-218, 1975.

Worton, D. R., Sturges, W. T., Schwander, J., Mulvaney, R., Barnola, J. M., and Chappellaz, J.: 20th century trends and budget implications of chloroform and related tri-and dihalomethanes inferred from firn air, Atmospheric Chemistry and Physics, 6, 2847-2863, 2006.

Yokouchi, Y., Noijiri, Y., Barrie, L. A., Toom-Sauntry, D., Machida, T., Inuzuka, Y., Akimoto, H., Li, H. J., Fujinuma, Y., and Aoki, S.: A strong source of methyl chloride to the atmosphere from tropical coastal land, Nature, 403, 295-298, 2000.

Yokouchi, Y., Ikeda, M., Inuzuka, Y., and Yukawa, T.: Strong emission of methyl chloride from tropical plants, Nature, 416, 163165, 2002.

Yokouchi, Y., Saito, T., Ishigaki, C., and Aramoto, M.: Identification of methyl chloride-emitting plants and atmospheric measurements on a subtropical island, Chemosphere, 69, 549-553, 2007.

Yoshida, Y., Wang, Y. H., Zeng, T., and Yantosca, R.: A threedimensional global model study of atmospheric methyl chloride budget and distributions, J. Geophys. Res.-Atmos., 109, D24309, doi:10.1029/2004JD004951, 2004.

Yoshida, Y., Wang, Y., Shim, C., Cunnold, D., Blake, D. R., and Dutton, G. S.: Inverse modeling of the global methyl chloride sources, J. Geophys. Res., 111, D16307, doi:10.1029/2005JD006696, 2006. 